ISBN 978-93-84468-92-7

International Conference on Issues in Education, Literature, Humanities and Social Sciences

(IELHSS-2017)

Kuala Lumpur (Malaysia) Jan. 4-5, 2017

\title{
Factors Affecting Consumer Behavior on Buying Products through Internet
}

\author{
Dr. Tosaporn Mahamud, and Qin Qichao \\ Postgraduate school of Business Administration, Kasembundit University, Bangkok
}

\begin{abstract}
The purpose of this study is to determine factors of behavior and marketing mix affecting consumer on buying products through Internet. This study was the quantitative study with the samplings for the study were 385 Chinese who live and bought products through Internet in China by using a questionnaire as a tool. The statistics used for data analysis were percentage, mean, standard deviation, Chi-Square, and regression analysis.

Findings from the survey indicated that most of respondents were females, age 26-30 years old, bachelor degree graduated, monthly income 15,000 baht, labor workers, and expenses each buying 1,500-2,500 baht through online payment. The overall picture of the opinions of factors affecting consumer behavior on buying products through Internet were in high level details as follows: Products aspect, contributed priority to the variety and description of the products, appropriated prices to quality of the products, shopping 24 hours, free delivery, and discount prices as a marketing promotion. The test of hypothesis revealed that the personal different, such as gender, age, occupation, level of education, and monthly income affected consumer behavior on buying products through Internet at significant level 0.01 and 0.05 and factors of marketing mix correlated to consumer behavior on buying products through Internet at significant level 0.05 .

Recommendations from the study were that e-commerce entrepreneur should prioritize on selecting a variety of products, emphasize on customer service, wide range of prices, webpage with modern design and display product details clearly, convenient and fast when buying products, and marketing promotion through discount prices and free delivery.
\end{abstract}

Keywords: Consumer Behavior, Products, Internet

\section{Introduction}

Nowadays, information technology has spread to almost every corner of the world, most of the countries that are ready and able to bring information technology as effectively, it will have advantages over competitor in business, until someone called the strategic use of information technology for business as "the new economy" and if it can increase their ability and other factors association with high technology to enhance the competitiveness of the country. The use of high technology into an important production factor in both the primary and the manufacturing process is a process improvement to resolve the variance of other inputs, such as labor and other resources.

Information technology (IT) is the application of computers and internet to store, retrieve, transmit, and manipulate data, or information, often in the context of a business or other enterprise. IT is considered a subset of information and communications technology (ICT).

So is the way to do business through the Internet network (e-Business) or (electronic business) in such manner as the sales format called electronic commerce or popularity is called e-commerce and the elements involved is similar to the common market. But e-commerce will be a gathering of information exchange with communication technology and the various steps. The seller and the buyer have the opportunity to compare and check the information of the products, prices, and services for price competition. 
Thailand's e-commerce market is booming and shaping up to be one of Asia's top performers. With the imminent start of the government's national e-payment system, aimed at making Thailand a cashless society, it's expected to see double-digit growth.

"In Southeast Asia, especially in Thailand, e-commerce is changing the way people think about shopping" explains Kulthirath Pakawachkrilers, an e-commerce specialist and the managing director of Joyfulness Co., a Bangkok-based technology consulting firm. "E-commerce and social commerce are becoming a major part of the shopping culture in Thailand."

"Thailand will be the hub of e-commerce and e-payments among ASEAN Economic Community (AEC) by 2017," she predicts.

The value of the e-commerce market was forecast to be 2.1 trillion baht (\$58.4 billion) in 2015, a 3.65 percent raise from 2014, reported the Electronic Transactions Development Agency (ETDA), a Thai governmental agency.

"Through our joint research with Google GOOGL $+0.26 \%$, we estimate that today 11 million consumers are doing online purchases in Thailand," says Sebastien Lamy, a partner at Bain \& Company and an expert in the firm's digital practice. "We believe that this number will double in the next three to five years, as demand continues to grow and digital offerings and the supporting logistics and payments infrastructures continue to improve."

Half of all online purchases in the country are made through mobile devices. According to a Bain study, that statistic spikes up considerably for consumers outside major metropolitan hubs, with 85 percent buying online with their mobile phones. It's expected to increase as the availability of nationwide 4G telecoms becomes widespread.

Revenue in the "e-Commerce" market amounts to US\$2,450m in 2016. Revenue is expected to show an annual growth rate (CAGR 2016-2021) of $16.7 \%$ resulting in a market volume of US $\$ 5,307 \mathrm{~m}$ in 2021 . The market's largest segment is the segment "Electronics \& Media" with a market volume of US\$1,117m in 2016. User penetration is at $20.9 \%$ in 2016 and is expected to hit $24.5 \%$ in 2021. The average revenue per user (ARPU) currently amounts to US\$211.60.

From introduction above, researcher are interested in determining of factors of behavior and marketing mix affecting consumer on buying products through Internet and the results of the study to be a guideline for ecommerce entrepreneur to use and prepare to improve their e-commerce businesses in order to meet customers demand.

\section{Purpose of the Study}

1. To study consumer behavior on buying products through Internet.

2. To study factors of marketing mix affecting consumer behavior on buying products through Internet.

Framework of the study

From study theory, literature, and concept, the researcher set the conceptual framework as follows:

\section{Conceptual framework of the study}

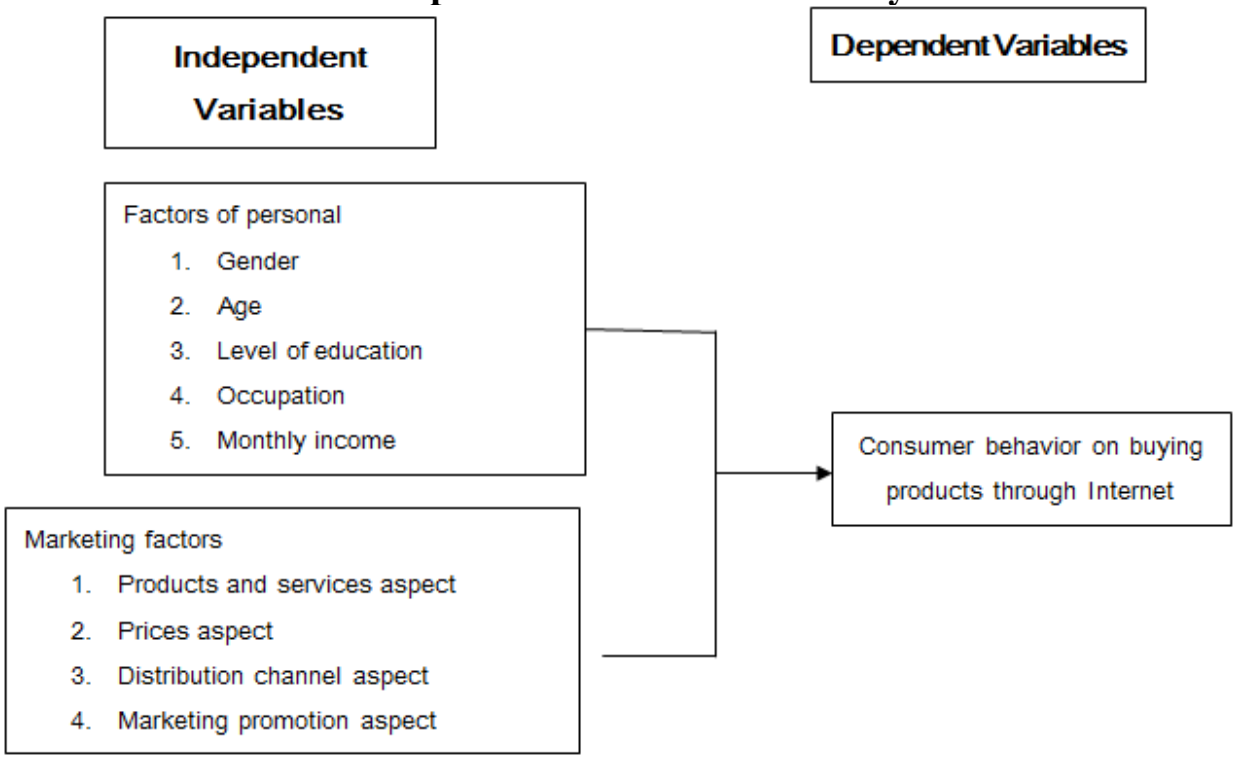




\section{Research Methodology}

\section{Sample selection}

This study was the quantitative study with the samplings for the study were 385 Chinese who live and bought products through Internet in China by using a questionnaire as a tool. The statistics used for data analysis were percentage, mean, standard deviation, Chi-Square, and regression analysis.

\section{Data collection procedure}

The questionnaires were distributed to sample of 385 Chinese who live and bought products through Internet in China by using a questionnaire as a tool. A total of 385 usable questionnaires were returned back to the researcher, yielding a 100 percent response rate and no missing data.

The results from the study of marketing mix affecting consumer behavior on buying products through Internet.

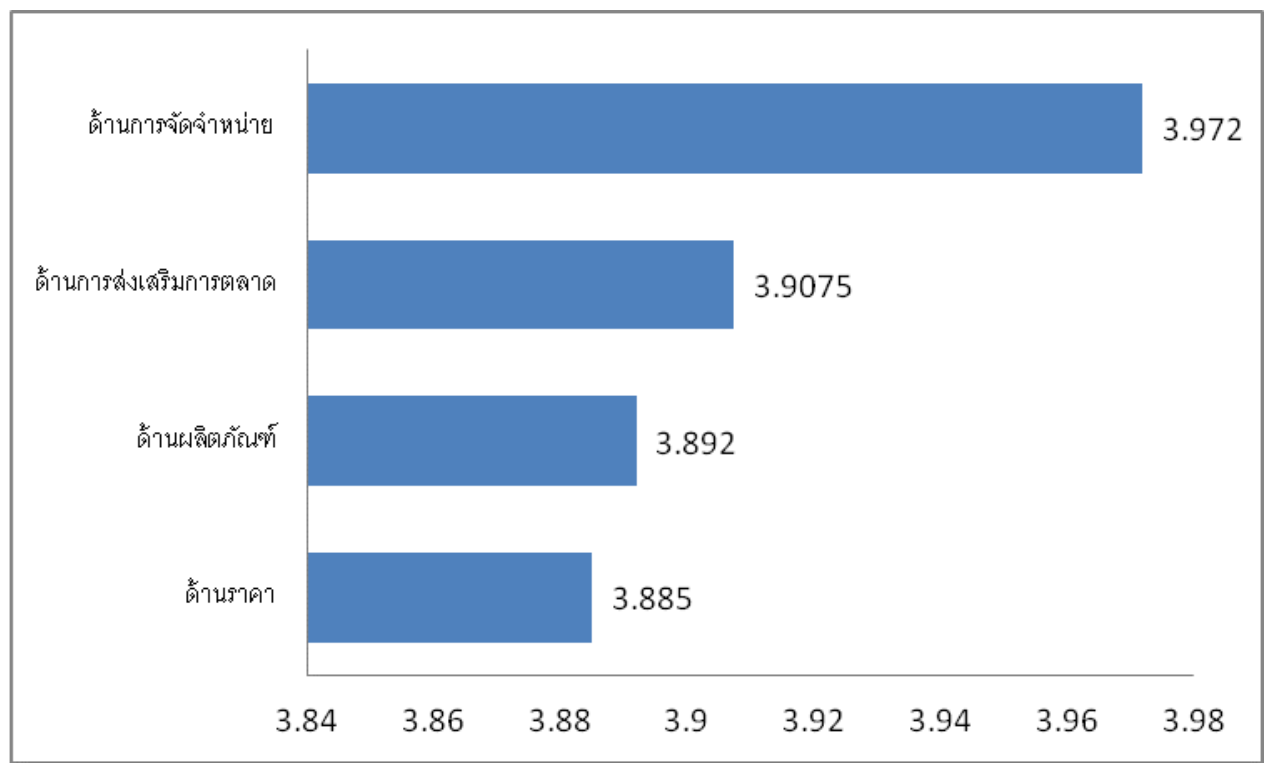

Fig. 1: shows the overall picture of the opinions of marketing mix affecting consumer behavior on buying products through Internet

From figure 1: The study results revealed that the overall picture of the opinion of marketing mix affecting consumer behavior on buying products through Internet were at high level, as for marketing promotion with overall picture $(\bar{x}=3.91)$, distribution channel aspect $(\bar{x}=3.97)$, marketing promotion aspect $(\bar{x}=3.91)$, products aspect $(\bar{x}=3.84)$, and prices aspect $(\bar{x}=3.89)$, respectively.

TABLE I: shows the test of hypothesis of regression value of the important of marketing mix affecting consumer behavior on buying products through Internet.

\begin{tabular}{|c|c|c|c|c|c|c|}
\hline Factors of marketing mix & B & $\begin{array}{l}\text { Std. } \\
\text { error }\end{array}$ & Beta & $\mathrm{t}$ & Sig. & results \\
\hline (constant) & 0.385 & 0.19 & & 2.026 & 0.046 & \\
\hline \multicolumn{7}{|c|}{ Products aspect } \\
\hline A variety of products & 0.021 & 0.072 & 0.027 & 0.2385 & 0.77 & $\begin{array}{l}\text { No } \\
\text { relationship }\end{array}$ \\
\hline Standard quality products & 0.126 & 0.098 & 0.158 & 1.287 & 0.202 & $\begin{array}{l}\text { No } \\
\text { relationship }\end{array}$ \\
\hline Display products with narration & 0.078 & 0.116 & 0.095 & 0.67 & 0.505 & $\begin{array}{l}\text { No } \\
\text { relationship }\end{array}$ \\
\hline Products reliable and services & -0.001 & 0.108 & -0.001 & -0.005 & 0.996 & $\begin{array}{l}\text { No } \\
\text { relationship }\end{array}$ \\
\hline Wide range of products & 0.257 & 0.116 & 0.28 & -2.217 & $0.030 *$ & relationship \\
\hline Reputation brand names products & 0.268 & 0.091 & 0.318 & 2.3852 & $0.005^{*}$ & relationship \\
\hline Service after sales & -0.083 & 0.112 & -0.105 & -0.741 & 0.461 & $\begin{array}{l}\text { No } \\
\text { relationship }\end{array}$ \\
\hline Reliable products & -0.2 & 0.126 & -0.223 & -1.585 & 0.117 & No \\
\hline
\end{tabular}




\begin{tabular}{|c|c|c|c|c|c|c|}
\hline Factors of marketing mix & B & $\begin{array}{l}\text { Std. } \\
\text { error }\end{array}$ & Beta & $\mathrm{t}$ & Sig. & results \\
\hline & & & & & & relationship \\
\hline Familiarity of products or services & 0.241 & 0.115 & 0.261 & 2.094 & $0.04 *$ & relationship \\
\hline \multicolumn{7}{|c|}{ Prices aspect } \\
\hline Appropriate prices with quality & 0.049 & 0.114 & 0.056 & 0.426 & 0.671 & $\begin{array}{l}\text { No } \\
\text { relationship }\end{array}$ \\
\hline Lower prices products & 0.299 & 0.101 & 0.354 & 2.946 & $0.004^{*}$ & relationship \\
\hline \multicolumn{7}{|c|}{$\frac{1}{\text { Distribution channel aspect }}$} \\
\hline 24 hours purchasing time & -0.023 & 0.099 & -0.028 & -0.237 & 0.814 & $\begin{array}{l}\text { No } \\
\text { relationship }\end{array}$ \\
\hline Accurately delivery & 0.073 & 0.112 & 0.085 & 0.647 & 0.52 & $\begin{array}{l}\text { No } \\
\text { relationship }\end{array}$ \\
\hline Update products prices frequently & 0.003 & 0.097 & 0.003 & 0.028 & 0.978 & $\begin{array}{l}\text { No } \\
\text { relationship }\end{array}$ \\
\hline Modern designed of distribution store & -0.006 & 0.085 & -0.009 & -0.067 & 0.947 & $\begin{array}{l}\text { No } \\
\text { relationship }\end{array}$ \\
\hline On time delivery & -0.074 & 0.117 & -0.097 & -0.629 & 0.531 & $\begin{array}{l}\text { No } \\
\text { relationship }\end{array}$ \\
\hline \multicolumn{7}{|c|}{ Marketing promotion aspect } \\
\hline Free delivery & 0.102 & 0.099 & 0.128 & 1.025 & 0.309 & $\begin{array}{l}\text { No } \\
\text { relationship }\end{array}$ \\
\hline Discount prices & 0.034 & 0.085 & 0.05 & 0.398 & 0.6385 & $\begin{array}{l}\text { No } \\
\text { relationship }\end{array}$ \\
\hline Free gift with purchased & 0.12 & 0.095 & 0.187 & 1.26 & 0.212 & $\begin{array}{l}\text { No } \\
\text { relationship }\end{array}$ \\
\hline Redemption coupons & 0.007 & 0.086 & 0.01 & 0.078 & 0.3858 & $\begin{array}{l}\text { No } \\
\text { relationship }\end{array}$ \\
\hline
\end{tabular}

*Significant level 0.05

From table 1: The results from the test of hypothesis of regression value at significant level 0.05 revealed that factors of marketing mix, a variety of choices of products aspect (Sig. $=0.03$ ), brand names reputation $(0.005)$, familiarity of products or services $(\mathrm{Sig} .=0.04)$, lower prices aspect $(\mathrm{Sig} .=0.004)$ correlated to consumer behavior on buying products through Internet at significant level 0.05 .

\section{Summary of Study Results}

This study was the quantitative study with the samplings for the study were 385 Chinese who live and bought products through Internet in China by using a questionnaire as a tool. The statistics used for data analysis were percentage, mean, standard deviation, Chi-Square, and regression analysis.

Summary of the result of factors of marketing mix affecting consumer behavior on buying products through Internet.

From the study revealed that the overall picture of the opinions of marketing mix affecting consumer behavior on buying products on the Internet were in high level consisted of the four major factors in descending order were distribution channel aspect, marketing promotion aspect, products aspect, and prices aspect with the following details:

Products aspect:

From the study of overall picture of the opinions of products aspect were in high level emphasized on a variety of products to select from, reliable products details and services, brand names reputation, services after sales, standard quality products, familiarity of products or services, display products with narration, respectively.

Prices aspect:

From the study of overall picture of the opinions of prices aspect were in high level emphasized on lower prices products and prices appropriate to the quality of the products.

Distribution channel aspect:

From the study of overall picture of the opinions of distribution channel aspect were in high level emphasized on delivery accurately, frequently update prices changed, always open for business, modern display distribution stores, and on time delivery, respectively. 
Marketing promotion aspect:

From the study of overall picture of the opinions of marketing promotion aspect were in high level emphasized on free delivery, discount prices, free gift with purchased, and coupon redemption.

\section{Recommendations from the Study}

Recommendations from the results of the study were that e-commerce entrepreneur should prioritize on:

1. Products aspect: a variety and quality of products, repackages of the products, and display products with narration.

2. Prices aspect: a wide range of prices with appropriate to the quality of the products.

3. Distribution channel aspect: clearly display products on the webpages, easy to navigate, and attractive webpages.

4. Marketing promotion aspect: distribute redemption coupons, free gift with purchased, discount prices, and free delivery.

\section{Suggestion for the Next Study}

The next research study, researcher should study on the in-depth interview, observing, or other technique in order to get more accurately result and for the benefit of the business entrepreneurs.

\section{References}

[1] Rattanachai Thapanapong. (2549). Factors affecting consumer decision on purchasing and servicing consumer electronic of private company employees in Bangkok.

[2] Ittachai Jakpitak. (2549). Strategy of making millions of online millionaire. C education, Bangkok.

[3] Santi Paksa. (2549). Factors of consumer decision on using products services on the Internet in capital district, Nakornpathom province. Thesis, Master of Business Administration, Ratchapath Suandusit University.

[4] Siriwan Saerirat \& Associate. (2542). Management strategy. Thera film and Sitex publisher, Bangkok.

[5] Kitsada Gonthup. (2550). Factors of consumer decision on buying products from Gonthup store. Capital district, Pannga province.

[6] Supaporn Chumsakul. (2554). Factors affecting consumer decision on purchasing and servicing The product on the Internet. Master of Business Administration.

[7] Rangsima Pedthong. (2555). Factors affecting consumer decision on purchasing and servicing consumer electronic of private company employees in Bangkok. 